\title{
Conversion of specialised dairy farming systems into sustainable mixed farming systems in Cuba
}

\author{
F. R. Funes-Monzote $\cdot$ Marta Monzote $\cdot$ \\ E. A. Lantinga $\cdot$ H. van Keulen
}

Received: 9 July 2007/ Accepted: 4 February 2008/Published online: 13 March 2008

(C) The Author(s) 2008

\begin{abstract}
From the 1960s onwards, a 'High External Input' dairy production model was applied widely in Cuba. Overall milk production of the national herd increased considerably, but the system was inefficient from both a financial and energetic point of view. In the early 1990s, after the abrupt end of inflow of capital and other resources from Eastern Europe, the dairy sector collapsed. In the short term, the modern infrastructure of milk production deteriorated and the sector experienced profound vulnerability. However, in the longer term, this situation stimulated a search for more sustainable approaches, such as low external input Mixed Farming Systems (MFS). The current study aimed to evaluate two small scale prototype farms to assess the implications of converting 'Low External Input' Dairy Farming Systems into MFS. Fifteen agro-ecological and financial indicators were
\end{abstract}

Readers should send their comments on this paper to: BhaskarNath@aol.com within 3 months of publication of this issue.

\section{F. R. Funes-Monzote}

Estación Experimental de Pastos y Forrajes ‘Indio Hatuey', Universidad de Matanzas, Central España Republicana, Perico, Matanzas, Cuba

F. R. Funes-Monzote $(\bowtie) \cdot$ H. van Keulen

Group Plant Production Systems, Wageningen University, Haarweg 333, 6709 RZ Wageningen, The Netherlands

e-mail: mgahonam@enet.cu; fernando.funes@wur.nl

\section{Monzote}

Instituto de Investigaciones de Pastos y Forrajes, Carretera 43, km 1 1/2, Cangrejeras, Bauta, 32400 Havana, Cuba

\section{E.A. Lantinga}

Group Biological Farming Systems, Wageningen University, Marijkeweg 22, 6709 PG Wageningen,

The Netherlands

H. van Keulen

Plant Research International, Wageningen University and Research centre,

P.O. Box 16, 6700 AA Wageningen, The Netherlands 
selected and monitored over a 6-year period. Two configurations of MFS, i.e. the proportion of the farm area occupied by arable crops, were tested: 25 and 50\%. Productivity, energy efficiency and cost-effectiveness all improved following conversion. Total energy input was low for both farms and decreased over time, whereas energy efficiency was high and increased over time. Human labour input was high directly following conversion, but decreased by one-third over the 6-year period. This study demonstrates, at an experimental scale, the potential of MFS to achieve ecological, productivity and financial advantages for dairy production in Cuba.

Keywords Agroecological indicators - Crop-livestock integration ·

Energy efficiency $\cdot$ Farm finance $\cdot$ Livestock production $\cdot$ Low external input

\section{Introduction}

From the 1960s until 1990, cattle husbandry in Cuba was based on specialised 'High External Input' systems, in which advanced technology was applied to produce milk in intensive, industrial systems and development strategies were focused on three fundamental aspects: genetics, infrastructure and feeding (Pérez 1999). As a result, national milk production increased to about 1 billion $\left(10^{9}\right)$ litres annually (ANPP 1991). However, production was inefficient, both financially and in terms of energy (Monzote et al. 2002). It has been estimated that in the 1980s, at the peak of industrial livestock production, the ratio of energy output to energy invested was 0.17 , i.e. only one-sixth of the energy input was exported in the form of milk and meat (Funes-Monzote 1998). The major components contributing to the energy inputs were fertilisers and pesticides (40\%), followed by molasses and other by-products from the sugar industry (25\%), concentrates (20\%), fuel (14\%) and human labour (1\%).

The 'High Input' model of livestock production was economically viable because of the favourable terms of trade with the socialist countries in Eastern Europe, in particular with the USSR. However, following political changes in the socialist block, Cuba plunged into a serious economic crisis (Funes et al. 2002). Moreover, the intensive livestock production systems, in combination with large-scale monoculture of industrial crops, had led to extensive deforestation, soil erosion and loss of biodiversity (CITMA 1997).

Awareness of the financial and energy inefficiency of the industrial specialised livestock production systems and of their negative environmental impacts, combined with increasing scarcity of capital and other inputs, triggered the development of new approaches in animal husbandry, aimed at on-farm feed and food self-sufficiency. The problems also challenged researchers to search for more efficient and environmentally sustainable milk and beef production systems (Monzote et al. 2002). In this search, various approaches have been attempted in order to develop more sustainable and self-sufficient cattle production systems, such as grass-legume associations, legume protein banks, silvo-pastoral systems, biofertilisers and selection of pasture species adapted to different regions. However, the main constraint for success was their isolated application and, in most cases, the lack of an integrative system perspective in technology development. A systems approach to development of a more productive and sustainable model of livestock production, based on principles of mixed farming, appeared a promising method.

Suitable environmental conditions for development of mixed farming systems (MFS) in tropical countries such as Cuba, include the high potential for biomass production because of the possibility of year-round production of highly productive $\left(\mathrm{C}_{4}\right)$ species and the high 
diversity of species with potential use for agriculture. These natural advantages, exploited through the use of high-yielding energy and protein crops and the inclusion of multipurpose leguminous trees, allow the design of promising crop-livestock systems. Such MFS have been widely developed in situations where either environmental conditions or socio-economic conditions were conducive (Van Keulen and Schiere 2004). In less-favoured areas, lack of external inputs often forced farmers to adopt MFS to make a livelihood from the limited available natural resources (Altieri 2002; Pretty et al. 2003; Van Keulen 2005). MFS have also been developed in more favourable environments with market-oriented systems, mainly under pressure of socio-economic (boundary) conditions (Lantinga et al. 2004).

Despite many examples of successful diversified 'Low External Input' systems, in Cuba it appeared difficult to convert the large monoculture farms into smaller-scale integrated systems. Low population densities in the rural areas, lack of capital and other inputs and the absence of appropriate infrastructure for smaller-scale livestock production were major constraints. It also appeared difficult to convince the Cuban authorities (particularly the Ministry of Agriculture) of the need for MFS, not only as an 'alternative', but as a 'leading' strategy for future development of the livestock sector. This could be due to the scarcity of local data. Long-term studies are necessary to gain understanding of the performance of MFS, as well as for evaluation of different combinations of crops and animals in a spatiotemporal framework.

To support this strategy, the current study was designed as the first stage of a broader project at the national level. It aimed to evaluate the conversion of a 'Low External Input' dairy farming system (DFS) into an MFS by monitoring the dynamics of 15 agro-ecological and financial performance indicators (AE\&FIs) over a 6-year period. The final goal is to identify potential integrated strategies for mixed farming, as a basis for sustainable livestock production in Cuba.

\section{Materials and methods}

\subsection{Experimental site}

The study was carried out between 1995 and 2000 at the Pastures and Forage Research Institute (IIPF), located in Western Havana City. The soil is a Haplic Ferralsol (eutric, clayic, rhodic) (WRB 2006) or Ferralítico rojo típico eutrico in the Cuban classification system (Hernández et al. 1999). Annual precipitation at the experimental site ranged from 1,300 to $1,500 \mathrm{~mm}$, of which about $70 \%$ fell between May and October (rainy season). Mean temperatures were 26.9 and $23.3^{\circ} \mathrm{C}$ in the rainy and dry season, respectively. Average relative humidity was between 82 and $85 \%$, with the highest values during the rainy season.

\subsection{Experimental design}

Two prototype mixed farms of one hectare each were established on the pasture area of a 15-ha specialised dairy farm, previously managed for about 5 years with low external inputs (i.e. fertilisers, concentrates, fuel, machinery) and low levels of productivity (yields of about $1.5 \mathrm{Mg}$ milk ha $^{-1}$ year $^{-1}$ ). For the purpose of this study, the data collected during the last year of operation of that farm, representing a typical dairy unit for the country, were set to year 0 of conversion. In the two mixed farms, 25\% (C25) and 50\% (C50) of the 
total farm area, respectively, was devoted to arable crops. Descriptions of the mixed farm designs and management practices are given in Fig. 1. The livestock sub-systems included pure grass $\left(\mathrm{A}_{1}\right)$ and grass-legume associations $\left(\mathrm{A}_{2}\right)$ in both $\mathrm{C} 25$ and $\mathrm{C} 50$, while a silvopastoral system $\left(A_{3}\right)$ was established in $C 25$. Legumes in $A_{2}$ were established by bandsowing at $25 \mathrm{~cm}$ distance in the original swards with minimum tillage (Monzote 1982), and the silvo-pastoral system by planting leguminous trees in $A_{3}$. Field $A_{1}$ in C50 was replanted with king grass (Pennisetum purpureum, Schum.) after plowing down the original sward and establishing living fences of leucaena [Leucaena leucocephala, (Lam.) de Wit.]. The forage areas in the livestock sub-systems $\left(\mathrm{B}_{1}\right.$ and $\left.\mathrm{B}_{2}\right)$ of $\mathrm{C} 25$ and the annual crop subsystems $\left(\mathrm{E}_{1}\right.$ and $\left.\mathrm{E}_{2}\right)$ of both farms were established following plowing down of the grass sward after removal of the herbage by heavy grazing.

Siboney cattle, a 5/8 Holstein-Friesian and 3/8 Cuban Zebu cross-breed, was used. During the study, one or two cows, depending on herbage availability, were kept in a put and take system on farm C25, and one on C50. Calves, born annually, were reared for 4 months in a restricted suckling nurse system and subsequently sold. Milk consumed by the calf is not included in the production data, only the sold live weight. Veterinary treatments were based on conventional methods. In addition, natural practices such as the use of entomopathogenic fungi, Verticillium lecanii (Rijo 1996) and Gavac vaccine for cattle tick control (Boue et al. 1999) were implemented.

Collected manure (about $10 \mathrm{~kg} \mathrm{cow}^{-1} \mathrm{~d}^{-1}$ ) and all available biomass, such as crop residues, animal feed refusals, weeds and some fresh legumes, were used for mulching or composted. Composting followed either of two methods: (1) static, aerobic or (2) vermi-

\begin{tabular}{|c|c|c|c|c|c|c|c|c|c|c|c|c|c|c|c|}
\hline \multirow{2}{*}{$\begin{array}{l}\text { Farm type } \\
\text { Farm area (ha) }\end{array}$} & $\mathrm{C25}$ & $A_{1}$ & \multicolumn{2}{|l|}{$A_{1}$} & $\mathbf{B}_{2}$ & & $A_{1}$ & $A_{1}$ & C50 & $E_{1}$ & $E_{1}$ & $E_{1}$ & $A_{2}$ & $\mathrm{~A}_{2}$ & \multirow[t]{2}{*}{$\mathrm{A}_{2}$} \\
\hline & 1 & D & & & C & & & \multirow[b]{2}{*}{$\mathrm{A}_{2}$} & \multirow{2}{*}{$\begin{array}{c}1 \\
1 \\
(2)\end{array}$} & D & \multicolumn{4}{|c|}{$\mathrm{C}$} & \\
\hline $\begin{array}{l}\text { Stocking rate } \\
\left(\mathrm{AU} \mathrm{ha}^{-1}\right)^{\mathrm{i})}\end{array}$ & $\begin{array}{c}1.8 \\
(2.5)\end{array}$ & $\mathrm{E}_{2}$ & $E_{1}$ & $\mathbf{E}_{1}$ & $\mathbf{E}_{1}$ & $\mathbf{E}_{1}$ & Ao & & & $\mathrm{E}_{2}$ & $E_{1}$ & $E_{1}$ & $A_{1}$ & $A_{2}$ & $A_{2}$ \\
\hline Reference & \multicolumn{4}{|c|}{ Land use type } & $\mathrm{FFA}^{\mathrm{ii} i}$ & & anagem & & \multicolumn{3}{|c|}{ Land use type } & FFA $^{\text {ii) }}$ & \multicolumn{3}{|c|}{ Management } \\
\hline \multicolumn{16}{|c|}{ Livestock Sub-system } \\
\hline $\mathbf{A}_{1}$ & \multicolumn{4}{|c|}{$\begin{array}{l}\text { Pure grass (mixture of star and } \\
\text { guinea grass). }\end{array}$} & $35 \%$ & & $\begin{array}{l}\text { tational } \\
\text { ices of } g\end{array}$ & $\begin{array}{l}\text { zing. Living } \\
\text { cidia. }\end{array}$ & \multicolumn{3}{|c|}{ Pure grass (king grass). } & $10 \%$ & \multicolumn{3}{|c|}{$\begin{array}{l}\text { Occasional grazing. Living } \\
\text { fences of leucaena. }\end{array}$} \\
\hline $\mathbf{A}_{2}$ & \multicolumn{4}{|c|}{$\begin{array}{l}\text { Grass/legume association (star and } \\
\text { guinea grass-perennial soybean, } \\
\text { centrosema, teramnus). }\end{array}$} & $10 \%$ & & tational & azing. & \multicolumn{3}{|c|}{$\begin{array}{l}\text { Grass/legume association } \\
\text { (brachiaria, guinea grass-tropical } \\
\text { kudzu, perennial soybean, } \\
\text { centrosema, teramnus). }\end{array}$} & $40 \%$ & \multicolumn{3}{|c|}{ Rotational grazing. } \\
\hline $\mathbf{A}_{3}$ & \multicolumn{4}{|c|}{$\begin{array}{l}\text { Silvo-pastoral system (Leucaena } \\
\text { trees) and grass/legume association } \\
\text { (guinea grass-teramnus). }\end{array}$} & $10 \%$ & & $\begin{array}{l}\text { casional } \\
\text { fresh sul } \\
\text { ar and lea }\end{array}$ & $\begin{array}{l}\text { zing. Pruning } \\
\text { es the whole } \\
\text { for hay. }\end{array}$ & \multicolumn{3}{|c|}{ (1) } & - & \\
\hline $\mathbf{B}_{1}$ & \multicolumn{4}{|c|}{ Sugar cane } & $10 \%$ & & $\begin{array}{l}\text { It and car } \\
\text { dry seas } \\
\text { the field. }\end{array}$ & $\begin{array}{l}\text { ystem during } \\
\text { Leaves remain } \\
\text { opping of stems. }\end{array}$ & \multicolumn{3}{|c|}{-} & - & \multicolumn{3}{|c|}{-} \\
\hline $\mathbf{B}_{2}$ & \multicolumn{4}{|c|}{ King grass } & $10 \%$ & & $\begin{array}{l}\text { it and ca } \\
\text { and. }\end{array}$ & system year- & \multicolumn{3}{|c|}{-} & - & \multicolumn{3}{|c|}{-} \\
\hline $\mathbf{C}$ & \multicolumn{15}{|c|}{ Corridor for the cattle. Free access to drinking water and grazing areas. } \\
\hline D & \multicolumn{15}{|c|}{ Open stable with drinking facility. Supply of fresh forages and hay. Collection of fresh dung and storage for composting. } \\
\hline \multicolumn{16}{|c|}{ Crop Sub-system iii) } \\
\hline $\mathbf{E}_{1}$ & \multicolumn{4}{|c|}{$\begin{array}{l}\text { Annual crops (corn/beans, } \\
\text { corn/squash, corn/beans/cassava) } \\
\text { and green manures (canavalia and } \\
\text { mucuna). }\end{array}$} & $20 \%$ & & op mixt & $\mathrm{s}$ in rotation & $\begin{array}{l}\text { Annual } \\
\text { corn/pes } \\
\text { and gree } \\
\text { mung be }\end{array}$ & $\begin{array}{l}\text { ps (con } \\
\text { ts, corn } \\
\text { nanure: } \\
\text { and } \mathrm{ml}\end{array}$ & $\begin{array}{l}\text { as, } \\
\text { s/cassava) } \\
\text { avalia, } \\
\text { ). }\end{array}$ & $45 \%$ & Crop & mixtures & rotation. \\
\hline $\mathbf{E}_{2}$ & Diversi & garden & & & $5 \% \mathrm{~V}_{\mathrm{c}}$ & $\begin{array}{l}\text { egetabl } \\
\text { om col }\end{array}$ & $\begin{array}{l}\text { les, frui } \\
\text { llected }\end{array}$ & $\begin{array}{l}\text { ees, spices and } \\
\text { g, crop residue: }\end{array}$ & $\begin{array}{l}\text { medicina } \\
s \text { and for: }\end{array}$ & $\begin{array}{l}\text { lants fe } \\
\text { refusa }\end{array}$ & $\begin{array}{l}\text { ed with wo } \\
\text { mpost he: }\end{array}$ & $\begin{array}{l}\text { orm humus } \\
\text { eap. }\end{array}$ & & compos & roduced \\
\hline
\end{tabular}

Fig. 1 Design and management practices in the two mixed farms (C25 and C50); open square indicates livestock sub-system, dark filled square indicates crop sub-system. ${ }^{\text {i) }} A U$ animal unit of $450 \mathrm{~kg}$ live weight; between brackets AU per ha livestock area. ${ }^{\text {ii) }}$ Fraction of farm area. ${ }^{\text {iii) }}$ Use of on-farm produced organic fertilisers (i.e. compost). Fruit trees planted between fields. Crop residues collected for animal feeding. Animal draught for soil preparation and cultivation 
composting using Californian red worms (Eiseniafoetida) based on the methods described by Ramón et al. (1987). Compost quality control included regular chemical analysis and temperature measurements.

\subsection{Assessment of agro-ecological and financial indicators}

Fifteen AE\&FIs (Table 1) were monitored over a 6-year period. Selection criteria for their choice were derived from: (1) critical points for sustainable development of livestock production (De Wit et al. 1995), i.e. relevant aspects that may constrain performance of livestock systems, (2) principal environmental problems identified in the Cuban National Strategy for the Environment (CITMA 1997) and (3) earlier assessments by Monzote et al. (1999).

All AE\&FIs were calculated (Table 1) on an annual basis for periods ending on October 31 , more or less coinciding with the end of the rainy season. Calculations on system productivity (yields per commodity, i.e. fruits, cash crops, animal products, production of energy and protein per hectare, number of people that can be fed) and energy balances were performed with the computer system ENERGIA (Sosa and Funes-Monzote 1998), developed for the purpose of this study.

\subsection{Data collection}

Animal and crop products were weighed at sale for productivity calculations. Number of species and individuals of plant and animal populations were counted once a year for biodiversity calculations. Labour spent directly on production activities, and other aspects of farm management were monitored daily. Quantities of compost were weighed before application.

\subsection{Soil analysis}

Soil analyses were carried out according to Paneque et al. (2002): soil $\mathrm{pH}\left(\mathrm{H}_{2} \mathrm{O}\right)$ by potentiometry in a soil-water suspension $(1: 2.5)$, available $\mathrm{P}$ by the Oniani method, exchangeable bases $\left(\mathrm{K}^{+}, \mathrm{Ca}^{2+} \mathrm{Mg}^{2+}\right.$ and $\left.\mathrm{Na}^{+}\right)$by the method of ammonium acetate, and soil organic matter (SOM) by the Walkley and Black method. In the latter method, commonly used in Cuba, dried soils are analysed for 'easily oxidisable carbon' using a wet chromic acid oxidation. Therefore, multiplication factors are required to obtain total organic carbon and subsequently SOM. A recovery factor of $77 \%$ is commonly used to convert 'easily oxidisable carbon' to total organic carbon (range 59-94\%; Allison 1960) and it is generally assumed that SOM contains 58\% carbon (range 30-62\%; Houba et al. 1997). For interpretation of the soil fertility characteristics, we used the classification of the handbook for soil interpretation of the Ministry of Agriculture of Cuba (DNSF 1982).

\subsection{Financial analysis}

Total Cost of Production was calculated from expenses for salaries of hired labour, contract labour, purchase of animals, veterinary care, equipment and materials, energy and seeds. The Total Value of Production for crop and livestock products was derived from the top retail market price, established by the Cuban Ministry of Agriculture (MINAG 2003; Appendix 1). Crop product prices not included in this list were set to half the average-free 
Table 1 Definition of the applied agro-ecological and financial indicators (AE\&FIs)

\begin{tabular}{lll}
\hline $\begin{array}{l}\text { Analysis } \\
\text { criterion }\end{array}$ & Indicator Unit Calculation method \\
\hline
\end{tabular}

Diversity

SR $\begin{gathered}\text { Margalef index } \\ \text { DP }\end{gathered} \quad \begin{array}{r}\text { Included are total number of species of crops, trees and } \\ \text { domestic animals; excluded are soil biota, spontaneous } \\ \text { vegetation or other plants and animals }\end{array}$
RDI Shannon index ${ }^{\mathrm{a}} \quad \begin{array}{r}\text { Included are the yield of each separate farm output and that } \\ \text { of the total system }\end{array}$
Shannon index ${ }^{\mathrm{a}} \quad \begin{array}{r}\text { Included are both the numbers of tree species and } \\ \text { individuals of fruit trees, timber and living fences }\end{array}$

Productivity

\begin{tabular}{|c|c|c|}
\hline MY & $\mathrm{Mg} \mathrm{ha}^{-1}$ year $^{-1}$ & Total milk production of the farm \\
\hline MYF & Mg ha ${ }^{-1}$ year $^{-1}$ & $\begin{array}{l}\text { Milk production per unit farm area directly used for animal } \\
\text { feeding (i.e. grazing areas, grass-legume associations, } \\
\text { cut forage areas and silvo-pastoral system) }\end{array}$ \\
\hline $\mathrm{EO}$ & GJ ha ${ }^{-1}$ year $^{-1}$ & Total energy in agricultural products \\
\hline PO & $\mathrm{kg} \mathrm{ha}^{-1}$ year $^{-1}$ & Total protein in agricultural products \\
\hline
\end{tabular}

Energy use

$\begin{array}{lll}\text { TEI } & \text { GJ ha } & \text { year } \\ \text { HLI } & \begin{array}{c}\text { Energy values of all inputs directly used for production } \\ \text { purposes }\end{array} \\ \text { ECP } & \text { MJ kg }^{-1} \text { day }^{-1} & \begin{array}{c}\text { Time spent on farm activities } \\ \text { Total energy used for production divided by total protein } \\ \text { output: TEI } \times 1,000 / P O\end{array} \\ \text { EE } & \text { GJ output GJ } & \text { Ratio between energy outputs and inputs } \\ & \text { input }^{-1} & \end{array}$

Financial performance

\begin{tabular}{|c|c|c|}
\hline NPV & & $\begin{array}{l}\mathrm{NPV}=\text { total value of production - sales taxes }(5 \%) \\
\text { post-harvest losses }(5 \%) \text { - on-farm price }\end{array}$ \\
\hline GM & 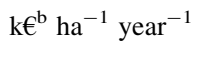 & $\begin{array}{l}\mathrm{GM}=\mathrm{NPV}-\text { total costs of production } \\
\quad(\text { fixed costs }+ \text { variable costs })\end{array}$ \\
\hline $\mathrm{BC}$ & & $\begin{array}{l}\mathrm{BC}=\mathrm{NPV} / \text { total costs of production } \\
\quad(\text { fixed costs }+ \text { variable costs })\end{array}$ \\
\hline
\end{tabular}

Nutrient regime

OFU $\quad \mathrm{Mg} \mathrm{ha}^{-1}$ year $^{-1} \quad$ Amounts of compost applied to crop areas

$S R$ species richness, $D P$ diversity of production, $R D I$ reforestation index, $M Y$ milk yield, $M Y F$ milk yield per forage area, $E O$ energy output, $P O$ protein output, $T E I$ total energy inputs, $H L I$ human labour intensity, $E C P$ energy cost of protein production, $E E$ energy efficiency, $N P V$ net production value, $G M$ gross margin, $B C$ benefit/cost ratio, $O F U$ organic fertiliser use

${ }^{\text {a }}$ For calculation procedures of Shannon and Margalef indices see Gliessman (2001)

${ }^{\mathrm{b}}$ one $€$ is about 1 CUC (Cuban Convertible Peso); 1 CUC $=24$ CUP (Cuban Pesos)

c The wholesale price was set to $70 \%$ of the retailer price. Fluctuating product prices and difficulties to obtain reliable wholesale prices of agricultural products made these estimations necessary

market prices, in accordance with the general trend in the list of MINAG. Strongly fluctuating product prices and difficulties in obtaining reliable wholesale prices of agricultural products made it necessary to use these estimates. In the calculations, 5\% post-harvest losses and 5\% sales taxes were taken into account.

For livestock products, i.e. milk and meat, farm gate prices were set to CUP 1.00 per litre of milk and CUP 2.05 per $\mathrm{kg}$ of beef. See Table 1 for conversion factors of CUP. 


\subsection{Data analysis}

Agro-ecological and financial indicators were presented using time series analyses of averages for the 6-year study period, with their respective standard deviations. Soil data were evaluated by ANOVA multiple comparison tests, using HSD-Tukey (Tukey 1977). Statistical analyses were carried out with SPSS (SPSS 1999).

\section{Results and discussion}

\subsection{Biodiversity}

The selected biodiversity indicators focus on three aspects: species richness, diversity of production and reforestation. These indicators are closely related to two of the major environmental problems associated with mono-cultural patterns of agriculture identified by the Cuban government, i.e. loss of biodiversity and deforestation (CITMA 1997).

The converted farms were characterised by the presence of large numbers of plant and animal species, i.e., about six times those at the beginning of the study (Table 2). Grain crops, root and tuber crops, vegetables, tree species, and new pasture and forage species were introduced in the design of the mixed farms. This allowed adaptation of the animal ration in the course of the year in response to seasonal climate patterns, especially rainfall, and the associated fluctuations in pasture production, one of the major problems in tropical livestock production systems (Funes 1979).

The Margalef index, as a measure of species richness, combines the total number of species in the system and the total number of individuals and reached values of 9.1 and 10.4 on the converted farms, thanks to the large number of species present (44 and 52,

Table 2 Performance of agro-ecological and productivity indicators in the specialised farm (year 0) and for the two mixed farms (C25 and C50) averaged over the 6-year period

\begin{tabular}{|c|c|c|c|c|c|c|}
\hline \multirow[t]{2}{*}{ Indicators } & \multirow[t]{2}{*}{ Units } & \multicolumn{5}{|c|}{ Farm system } \\
\hline & & Year 0 & $\mathrm{C} 25$ & $\mathrm{SD}$ & $\mathrm{C} 50$ & SD \\
\hline Species richness & Margalef index ${ }^{a}$ & $1.6(8)^{\mathrm{b}}$ & $10.4(52)$ & 0.55 & $9.1(44)$ & 1.59 \\
\hline Diversity of production & Shannon index & $0.2(2)$ & $1.7(23)$ & 0.37 & $2.0(17)$ & 0.17 \\
\hline Reforestation index & Shannon index & $0(0)$ & $1.7(204)$ & 0.06 & $1.5(131)$ & 0.10 \\
\hline Milk yield per unit farm area & Mg ha ${ }^{-1}$ year $^{-1}$ & 1.8 & 2.4 & 0.95 & 2.0 & 0.50 \\
\hline Milk yield per unit forage area & $\mathrm{Mg} \mathrm{ha}^{-1}$ year $^{-1}$ & 1.8 & 3.1 & 1.25 & 4.0 & 0.99 \\
\hline Energy output & GJ ha ${ }^{-1}$ year $^{-1}$ & 7.2 & 16.4 & 2.63 & 27.1 & 5.89 \\
\hline Protein output & $\mathrm{kg} \mathrm{ha}^{-1}$ year $^{-1}$ & 91.0 & 133.5 & 36.94 & 191.3 & 42.90 \\
\hline Labour intensity & Hour ha ${ }^{-1}$ day $^{-1}$ & 1.9 & 3.9 & 1.50 & 5.7 & 1.17 \\
\hline Total energy input & GJ ha ${ }^{-1}$ year $^{-1}$ & 3.1 & 2.0 & 0.93 & 2.8 & 0.59 \\
\hline $\begin{array}{l}\text { Energy cost of protein } \\
\text { production }\end{array}$ & $\mathrm{MJ} \mathrm{kg}^{-1}$ & 34.1 & 14.8 & 4.98 & 14.9 & 2.06 \\
\hline Energy efficiency & GJ output $\mathrm{GJ}^{-1}$ input & 2.3 & 9.6 & 3.43 & 9.8 & 2.10 \\
\hline Organic fertiliser use & $\mathrm{Mg} \mathrm{ha}^{-1}$ & - & 5.3 & 1.59 & 5.0 & 1.98 \\
\hline
\end{tabular}

${ }^{a}$ For calculation procedures of Shannon and Margalef indices see Gliessman (2001)

b Between brackets, absolute number of trees, species and products 
respectively), compared to only eight pasture species in year 0 and a corresponding index of 1.6 (Table 2). This index provides a more meaningful measure of the diversity at farm level than one only accounting for the total number of species. The large number of plant and animal species was associated with a large diversity in production (17 and 23 products, respectively), compared to only milk and beef before the conversion (Table 2).

Both farms were characterised by large numbers of trees per hectare (131 and 204, respectively), due to the establishment of trees as forage sources for animals, as well as for living fences and fruit production. Trees are an important component in MFS in the tropics. Research in Cuba and the Central American region (Benavides 1998; Hernández et al. 2001) has revealed increases in milk and meat production, and improvements in animal welfare in livestock systems following introduction of trees, especially leucaena and other leguminous species. Our results indeed indicate that trees, as major components of MFS diversification, had a positive effect on farming system productivity in terms of milk yield, energy and protein output, as tree products such as leaves, were essential components of the animal ration. Moreover, due to the deeper rooting of trees, nutrients can be 'pumped' from the sub-soil (Breman and Kessler 1995).

The indicators of diversity of production and reforestation are both expressed in the Shannon index, which combines either the number of products or of tree species (diversity) with the yield per product or the number of individuals per species (abundance). Shannon indices tend to be higher when the distribution of species and individuals is more even, and for relatively diverse natural ecosystems may rank between 3 and 4 (Gliessman 2001). In our mixed farms, high values of the indices of diversity of production (1.7-2) and reforestation (1.5-1.7) were attained, compared to year 0 , when diversity of production was 0.2 and trees were absent. They were also appreciably higher than the values (up to 0.48) calculated for hypothetical multicropping agro-ecosystems, with two or three species and high evenness (Gliessman 2001).

Application of the Shannon and Margalef diversity indices, originally developed for evaluation of natural ecosystems, for analysis of agro-ecosystem diversity might lead to increased insight in the contribution of crop and animal diversification to the improvements in productivity, efficiency and financial indicators of mixed systems.

The increase in plant diversity also affected diversification in other aspects. In our two mixed farms, 15 natural enemies controlling potential pests have been identified (PérezOlaya 1998). Perennial crops, such as grasses, gliricidia [Gliricidia sepium, (Jacq.) Kunth ex Walp.] and leucaena acted as alternative hosts for natural enemies of crop pests. These observations are in line with those of Vandermeer et al. (1998) and Altieri (1999), i.e. system diversification stimulates emergence of natural enemies controlling pests, contributing to sustainability of agricultural systems.

Moreover, soil fauna biodiversity and the activity of soil biota (diplopods and worms) have been shown to increase following conversion to MFS (Rodríguez 1998).

\subsection{Productivity}

Productivity is probably the most extensively used indicator in agronomic performance analyses. This study took into account four indicators for productivity of the farm: milk production per unit farm area and per unit forage area, and total energy and protein output.

Milk yield per unit farm area was somewhat higher than before the conversion to mixed farming (Table 2), although up to $50 \%$ of the total farm area was used for arable and horticultural crops, and therefore not directly for producing animal feed. This increase was 
the result of the introduction of various innovations in the mixed farms; e.g. cultivation of high-yielding perennial forages, grass-legume associations and leguminous trees and use of crop residues as animal feed, resulting in more and better quality animal feed throughout the year. This also led to a high milk yield per unit forage area after conversion (Table 2).

Given that the Cuban government has defined the social mandate of the dairy sector as: 'to produce milk for children, elderly and sick people', increasing milk production is a political priority. However, biophysical and socio-economic constraints have reduced current total milk production in Cuba to about one-third of that in the 1980s (González et al. 2004) and present-day average annual yields in specialised commercial dairy production units do not exceed $1 \mathrm{Mg}$ of milk per hectare of farmland (MINAG 2006). In commercial dairy farming, based on pasture and medium levels of concentrates, under 'outstanding management', production up to $3 \mathrm{Mg}$ per hectare is possible (García Trujillo 1983). In year 0 of this study, the original specialised system produced $1.8 \mathrm{Mg} \mathrm{ha}^{-1}$, while in the mixed farms, annual yields of 3.1 and $4 \mathrm{Mg}$ per hectare forage area were attained (Table 2).

In terms of total production (expressed in energy and protein, the two main components in human nutrition), livestock products in the mixed farms exceeded the yields in year 0 , on top of which crop products were harvested. The highest energy (27.1 GJ ha ${ }^{-1}$ year $^{-1}$ ) and protein (191.3 $\mathrm{kg} \mathrm{ha}^{-1} \mathrm{year}^{-1}$ ) outputs (Table 2), achieved at farm C50, were associated with high 'additional' crop production.

Productivity can also be expressed in terms of the number of people that can be fed from the protein or energy output of a system. Averaged over the 6-year period, in farm $\mathrm{C} 25$ the energy produced was enough to adequately feed four people, with protein for up to five, while in C50 these numbers were six and eight, respectively. These numbers are about twice as high as reported in literature for medium-intensity specialised milk production systems (Spedding 1988; Beets 1990) and at least four times higher than currently achieved in the 'Low External Input' specialised dairy systems in Cuba.

\subsection{Energy use}

\subsubsection{Labour}

Human labour productivity is an essential indicator in performance assessment of MFS strategies in dairy farms in Cuba, because of the scarcity of this 'resource' in rural areas. Although labour-intensive designs were implemented, in practice labour input gradually decreased over time on farm C25, while on farm C50 it showed a parabolic pattern with a maximum in year 3 (Fig. 2a). Concurrently, production was maintained and therefore labour productivity increased. The higher labour demand of both mixed farms in the first years can be attributed to the initially higher number of farm activities, such as sowing legumes in grazing areas, conversion of pasture into arable land, fencing, planting of trees, establishing the crop rotation system, weed control, etc. Over the 6 years, total labour input was lower in $\mathrm{C} 25$ than in $\mathrm{C} 50$, due to the smaller cropping area.

Our results are relevant for the three major segments of present livestock production in Cuba: (1) the growing sector of small producers that received land from the state in usufruct, currently about 400,000 (Granma 2006), each with up to 5 ha of land, managed with labour-intensive methods; (2) the small farmers sector, cultivating private land and producing individually or organised in cooperatives such as Credit and Services Cooperatives and Agricultural Production Cooperatives at intermediate levels of productivity, but 


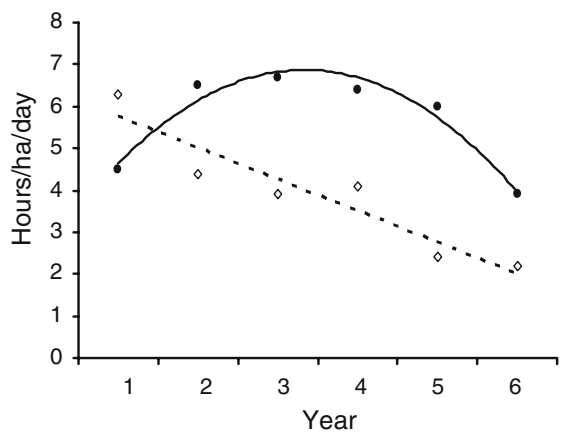

a) Human Labour Intensity

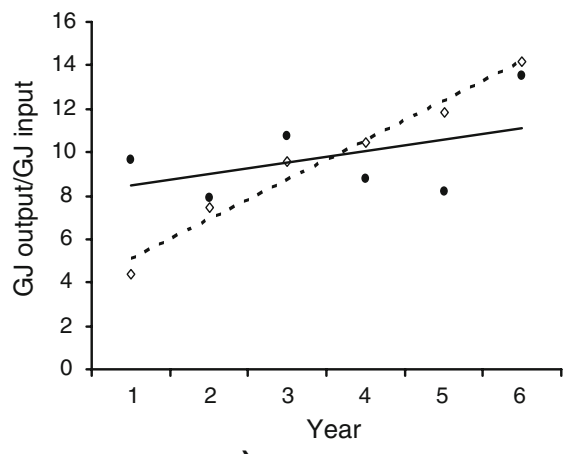

c) Energy Efficiency

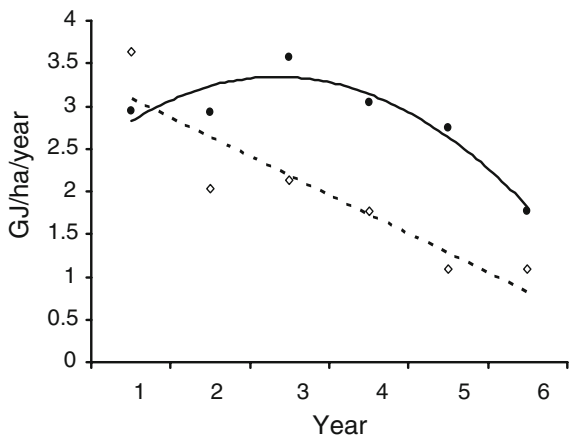

b) Total Energy Inputs

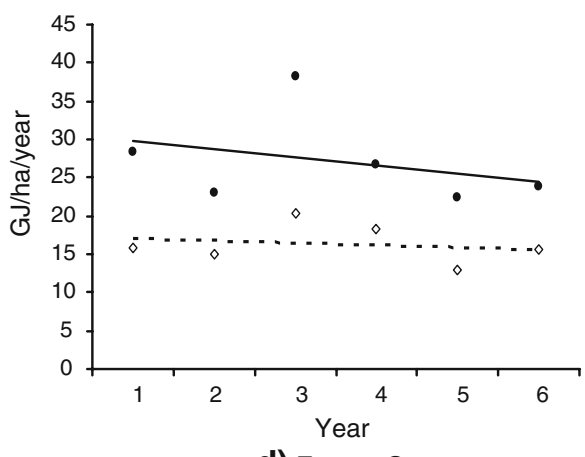

d) Energy Output

Fig. 2 Dynamics of human labour intensity (a), total energy inputs (b), energy efficiency (c) and energy output (d) on mixed farms with 25 and $50 \%$ crop area, following conversion from a pasture-based dairy system. Dotted lines indicate C25 and straight line indicates C50

in most cases at low levels of crop-livestock integration and (3) the Basic Units of Cooperative Production (UBPC) that started in 1993 under Law 142. This law regulated partitioning of previous state cattle holdings into smaller units, encouraging diversification and adopting a family farm model. In total, these three segments affect about 4.2 million ha of Cuba's agricultural land. However, recent estimates set the area of abandoned land at roughly three million hectares, i.e. about half of Cuba's agricultural area, belonging for the greater part to the UBPC and state enterprises. Two possible directions to reverse this development are promotion of either extensive or small-scale intensive livestock-croptree mixed farming with low environmental impact. Under both scenarios, many of the 'Low External Input', low labour-intensive and high-efficiency natural resource management practices implemented in the current study are applicable. However, further simplifying managerial activities continues to be a goal, considering that labour availability remains a primary constraint, as the population has moved out of the rural areas.

\subsubsection{Energy inputs}

Increasing the efficiency of input use was identified as an important objective in the management of the prototype mixed farms. The small sizes of the two experimental farms allowed use of animal traction and intensive human labour, instead of mechanised 


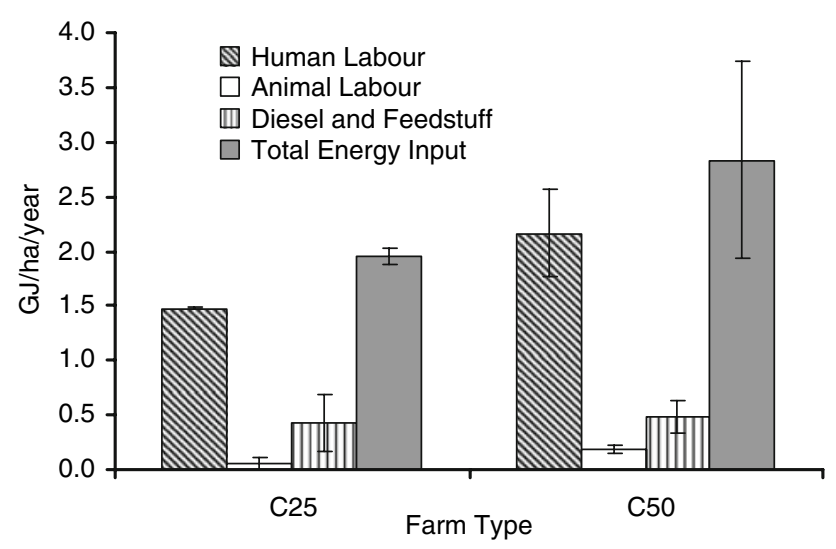

Fig. 3 Average energy input use on mixed farms with 25 and 50\% crop area for the 6-year period following conversion from a pasture-based dairy system. Error bars indicate the standard deviation of the mean

operations. Human labour was the largest component in energy inputs on both mixed farms that were designed as labour-intensive management systems, with the other components (i.e. diesel and feedstuffs) accounting for about $20 \%$ of the total (Fig. 3). Energy input linearly decreased with time since establishment on farm C25, while on farm C50 it showed a parabolic pattern with a maximum in year 3, in parallel to the labour inputs (Fig. 2b), and was lower on farm C25, due to the smaller area devoted to crop production. Realizing high levels of production, at the lowest possible level of inputs (Hilhorst et al. 2001) would indeed be an advantage under the conditions of scarcity and uncertain supply of inputs prevailing in Cuba. This is a strong argument in favour of continuation of MFS, even when the economic situation improves.

\subsubsection{Energy efficiency}

Higher energy efficiencies on the mixed farms were primarily the result of transformation of part of the pasture area into arable crops, leading to an increase in total energy output and a reduction in total energy input (Table 2). Energy efficiency shows an increasing trend with time after conversion on both farms, associated with decreases in total energy input, mostly in the form of human labour, while energy output was stable (Fig. 2a-d).

In energy terms, protein was produced more efficiently in the mixed systems (i.e. lower energy costs of protein production than in the specialised system. Moreover, although energy efficiencies in animal and crop production systems have a different biological basis (Spedding 1988; Stout 1990), our results indicate that higher production of animal protein per unit forage area can be attained using MFS strategies. This type of farm-scale energy efficiency analyses is consistent with studies of Pimentel (2004) and Giampietro et al. (1994) who in sustainability analyses, focused on energy flows in food production at system level. Energy conversion analyses should not be considered as an alternative to financial analyses, but rather as a complement to better cover the complex web of interrelationships between finances and the environment in which food systems operate (Giampietro et al. 1994).

In countries where fossil energy is abundantly available or where the use of high energy inputs is subsidised, energy-intensive farming systems do not face many technical constraints. However, for countries such as Cuba, where energy and/or capital are scarce 
resources, energy efficiency is a critical issue for national food security (Funes-Monzote and Monzote 2001). Furthermore, economic considerations such as high oil prices on the international market and environmental issues such as global warming associated with $\mathrm{CO}_{2}$ emissions, and the pollution of water and air, are leading societies worldwide to demand more responsible use of fossil energy. High dependence on fossil fuels is generally considered an indicator of low sustainability. Renewable energy alternatives such as biogas, wind power, solar energy, biomass and biofuels, have high potential applications for the development of energy self-sufficient agricultural systems (Pimentel et al. 2002).

\subsection{Financial results}

Our two mixed farms achieved higher gross margins and higher benefit-cost ratios than the specialised farm (Table 3). This is the result of the inclusion of arable crops, the high productivity per unit farm area, and the higher prices for crop products than for milk and meat (Appendix 1). Therefore, increasing whole farm income by selling crop products in regions where arable farming is possible, might be a suitable strategy for supporting cattle operations and making dairy farming more attractive. This is in line with the results presented by De Koeijer et al. (1995) and Thomson et al. (1995) who have indicated financial advantages of MFS, as a result of a more intensive use of natural resources and beneficial interactions between crop and livestock production.

The total value of production was higher in the two mixed systems than in the specialised dairy system in year 0 , but the total costs of production were also higher, associated with the higher labour costs and the capital demand to establish the crop production activities (Table 3). Economic incentives are important to sustain or to increase the population in rural areas. However, lack of incentives and centralised top-down decisions constrain development of the dairy sector. The price of milk for the consumer in the vulnerable sectors of the population is set to $0.25 \mathrm{CUP} /$ litre by the government, the only

Table 3 Performance of financial indicators in the specialised farm (year 0) and the two mixed farms (C25 and C50) averaged over the 6-year period

\begin{tabular}{|c|c|c|c|c|c|}
\hline \multirow{2}{*}{$\begin{array}{l}\text { Financial indicators } \\
\left(\mathrm{kCUP} \mathrm{ha}^{-1} \text { year }^{-1}\right)\end{array}$} & \multicolumn{5}{|c|}{ Farm system } \\
\hline & Year 0 & $\mathrm{C} 25$ & SD & $\mathrm{C} 50$ & SD \\
\hline Total value of production & 2.49 & 8.65 & 2.03 & 15.25 & 5.34 \\
\hline Value of crop production & - & 6.03 & 2.09 & 13.02 & 5.15 \\
\hline Value of livestock production & 2.49 & 2.62 & 0.92 & 2.23 & 0.59 \\
\hline Net production value & 2.49 & 6.11 & 1.31 & 9.93 & 3.29 \\
\hline Total costs of production & 1.87 & 3.51 & 1.15 & 4.86 & 0.81 \\
\hline Salaries & 0.79 & 1.64 & 0.64 & 2.38 & 0.49 \\
\hline Purchase of animals & 0.50 & 0.20 & 0.32 & 0.20 & 0.32 \\
\hline Veterinary treatments & 0.04 & 0.06 & 0.02 & 0.04 & 0.00 \\
\hline Equipment and materials & 0.20 & 0.52 & 0.02 & 0.59 & 0.02 \\
\hline Diesel & 0.25 & 0.17 & 0.01 & 0.42 & 0.02 \\
\hline Seeds & 0.09 & 0.91 & 0.32 & 1.23 & 0.32 \\
\hline Gross margin & 0.62 & 2.60 & 0.67 & 5.07 & 2.83 \\
\hline Benefit-cost ratio (-) & 1.33 & 1.74 & 0.38 & 2.04 & 0.50 \\
\hline
\end{tabular}

One $€$ is about 1 CUC (Cuban Convertible Peso); 1 CUC $=24$ CUP (Cuban Pesos) 
official milk processor and retailer, while the producer price is set to about $1.00 \mathrm{CUP} /$ litre, which is low, considering the costs of production. Therefore, milk production is a lowincome activity, not economically attractive for producers. While a reduction in the cost price of milk is difficult to realise in low external input DFS, in MFS, milk production tends to become more feasible when combined with other, highly profitable activities such as cash crop and fruit production.

The results of this study are not in contradiction with the national policy of prioritisation of the dairy sector. To be politically acceptable, any diversification strategy should first demonstrate that it does not negatively affect the 'main goal' of producing milk, associated with the 'social mandate' given to livestock enterprises. Hence, any MFS strategy should be able to produce milk with 'minimal environmental damage' and at low costs in external inputs.

Moreover, if economic or political changes lead to price increases for milk and meat, other goals, related to environmental protection and sustainable rural development will be sufficiently important to retain mixed farming on Cuba's future agricultural agenda.

Farms in the UBPCs are increasingly turning towards prioritising diversification for self-sufficiency (feeding workers and their families at low costs and selling possible surpluses in local or external markets to improve their financial sustainability), which makes these results even more relevant. Other emergent activities that might be combined in diversified MFS such as agro-tourism, nature conservation and education are also attractive options and need to be seriously considered. However, as indicated before, structural changes and economic incentives are necessary to stimulate the return of people to the rural areas and make economic use of available land. Our results show that the importance of the financial impact of adopting MFS to promote changes in Cuban agriculture should not be underestimated.

\subsection{Soil fertility}

Soil fertility of the Ferralsols in year 0 was classified as medium. According to DNSF (1982), the content of SOM was low and $\mathrm{pH}$ moderately to slightly acid. Levels of available $\mathrm{P}$ and exchangeable $\mathrm{K}^{+}$were medium, while the sum of exchangeable cations ( $\mathrm{SEC}=$ base saturation) was half the 'typical' values for this type of soil (around 20).

After conversion to mixed farming, SOM contents tended to increase. Although in some fields this increase was statistically significant, these data should be interpreted with caution. In the Walkley and Black analytical method it has been assumed for the calculation of SOM that $77 \%$ of the organic carbon is oxidised and that SOM contains $58 \%$ carbon. Since these are average values that may vary widely, depending on soil type and management practices, respectively, the results in terms of changes in SOM over time after adaptations in soil management, are highly uncertain.

Soil $\mathrm{pH}$ increased slightly and remained moderately to slightly acid, except in the cash crop $\left(C_{1}\right)$ and the diversified garden $\left(C_{2}\right)$, where it increased significantly. Available $P$ decreased to low in $A_{1}$ and $A_{3}$, remained medium in $A_{2}$ and $B_{2}$ and increased to high in $B_{1}$, $\mathrm{C}_{1}$ and $\mathrm{C}_{2}$; however, the differences were not statistically significant. Exchangeable $\mathrm{K}^{+}$ changed very little, except in sugar cane (Saccharum officinarum, L.) $\left(\mathrm{B}_{1}\right)$ and in king grass $\left(\mathrm{B}_{2}\right)$ where it declined. SEC hardly changed, and remained low for all land use types (Table 4).

The application of on-farm produced compost and vermi-compost at annual doses of between 4 and $6 \mathrm{Mg} \mathrm{ha}^{-1}$ in the crop sub-system, and other soil-restoring practices such as 


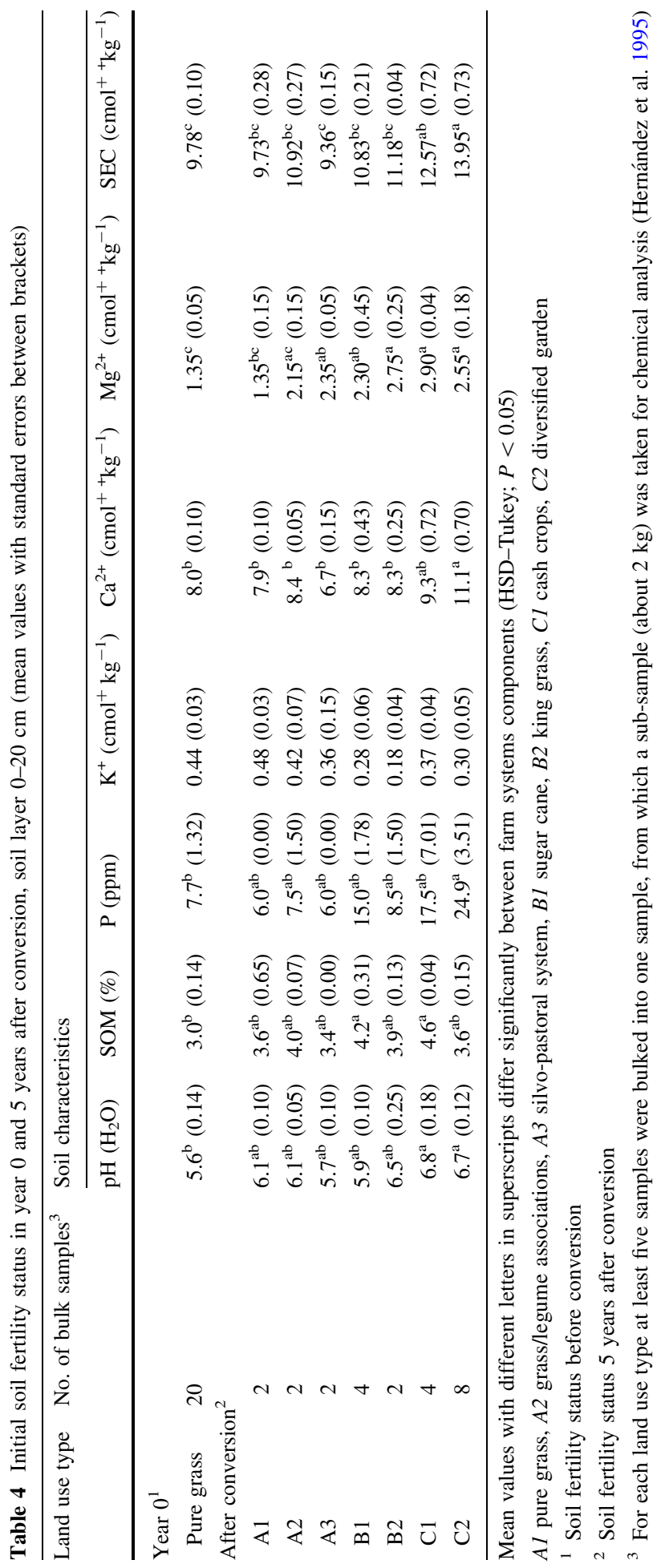


planting legumes and trees, and mulching, might allow maintaining or even slightly increasing SOM in the arable land (De Ridder and Van Keulen 1990). However, roughly $40 \mathrm{Mg}$ of compost per ha should have been added annually during 5 years to increase SOM by $1 \%$ (B. H. Janssen, Group Plant Production Systems, Wageningen University, pers. comm.). Such quantities were certainly not incorporated in the mixed systems, confirming the uncertainties associated with the Walkley and Black method.

The slight decrease in available $\mathrm{P}$ in the grazing sub-system may be attributed to the continuous phosphorus export through sales of milk and meat, and manure collected in the stable (about 3.6 Mg annually). Increases in $\mathrm{SOM}, \mathrm{pH}$ and available $\mathrm{P}$ have been reported in a silvo-pastoral system in Cuba (Crespo and Rodríguez 2000). Hence, there was no reason to expect $\mathrm{P}$ depletion in the silvo-pastoral sub-system. However, studies in Australia and New Zealand have shown acidification effects as a consequence of biological Nfixation of legumes, leading to a reduction in availability of some nutrients such as $\mathrm{P}$ (Haynes 1983; Helyar and Porter 1989; Ledgard and Steele 1992). In the king grass subsystem, apparently $\mathrm{K}$ is being depleted and needs to be restored. This process has been extensively documented (Herrera 1990) and maintenance of a favourable soil K-status in high-yielding forage areas should be a goal in any MFS.

The overall picture arising from these data is that as a result of nutrient exports from the farm in the form of products, and the redistribution of nutrients via organic transfers, nutrients accumulate in some of the arable fields, while some other fields (particularly pastoral) are 'mined' (Hiernaux et al. 1998; Archard and Banoin 2003). This is especially true for $\mathrm{P}$ and $\mathrm{K}$. The information on carbon dynamics is inconclusive, as there is doubt about the quality of the analytical data. However, accumulation seems to take place in the arable sub-systems, especially the annual crops and the sugar cane. Medium-term rotation (5-7 years) of the crop and livestock sub-systems might be a solution to this problem. However, longer-term research is necessary to establish the long-term effects of rotations and in general of agro-ecological management on soil fertility at farming system level.

\section{Conclusions}

More intensive use of the available natural resources at the farming system level, through diversified MFS in terms of both crop and milk production, contributes to food selfsufficiency and to efficient production of marketable products that contribute to household incomes without degrading the resource base.

Despite the small scale of the current experiment, its potential impact is large. More than two million hectares of land in Cuba are used in specialised milk or meat production systems, managed essentially according to the same principles used prior to 1990, while the institutional environment, in terms of infrastructure and availability of inputs, has changed drastically. Moreover, current livestock developments take place on small- and medium-scale family farms (in both individual and cooperative forms of production), to which the results of this study are potentially applicable.

The lack of capital to maintain conventional high-input systems, the necessity of increasing the level of national food self-sufficiency and the need to restrict negative impacts on the environment are not only issues for Cuba, but also for other developing and developed countries.

Acknowledgements This research was part of the National Project 0800058 'Designs for crop-livestock integration at small and middle scale' financed by the Ministry of Science, Technology and Environment of 
Cuba. Thanks to the International Foundation for Science in Sweden for the scientific support and funds, which helped to carry out part of this study under the research grant B/3213 and the former Promotion Group of the Cuban Association of Organic Agriculture and the UNDP-SANE Project (Sustainable Agriculture Networking and Extension). We are grateful to Eng. Didiel Serrano and Gabriel de la Fe for their assistance in the fieldwork. Fernando R. Funes-Monzote dedicates this publication to the memory of his mother, Dr Marta Monzote, who also co-authored the paper but unfortunately passed away prior to its completion.

Open Access This article is distributed under the terms of the Creative Commons Attribution Noncommercial License which permits any noncommercial use, distribution, and reproduction in any medium, provided the original author(s) and source are credited.

\section{Appendix 1}

Retail prices in the free market and regulated by the Ministry of Agriculture (MINAG) of Cuba

\begin{tabular}{|c|c|c|c|c|c|}
\hline \multirow[t]{2}{*}{ Product } & \multicolumn{2}{|c|}{ Price (in CUP $\mathrm{kg}^{-1}$ equivalent) } & \multirow[t]{2}{*}{ Product } & \multicolumn{2}{|c|}{ Price (in CUP $\mathrm{kg}^{-1}$ equivalent) } \\
\hline & Free market & MINAG 2003 & & Free market & MINAG 2003 \\
\hline Anonna & 11.1 & 5.6 & Okra & 11.1 & 4.4 \\
\hline Avocado & 10.0 & 2.0 & Onion & 22.2 & 11.1 \\
\hline Banana 'burro' & 2.0 & 1.3 & Onion leaves & 6.7 & 2.2 \\
\hline Banana 'fruit' & 4.0 & 2.0 & Orange & 4.0 & 1.3 \\
\hline Beans & 22.2 & 13.3 & Oregano & 4.4 & 2.2 \\
\hline Cabbage & 2.5 & 0.5 & Papaya & 8.9 & 4.0 \\
\hline Carrot & 11.1 & 3.3 & Parsley & 4.4 & 2.2 \\
\hline Cassava & 5.3 & 1.8 & Passion fruit & 10.0 & 5.0 \\
\hline Corn, grain & 8.9 & 4.4 & Peanuts & 22.2 & 11.1 \\
\hline Coriander & 4.4 & 2.2 & Pineapple & 15.4 & 4.4 \\
\hline Cucumber & 8.9 & 2.2 & Plantain & 10.0 & 4.9 \\
\hline Custard apple & 6.3 & 3.1 & Pumpkin & 4.4 & 1.1 \\
\hline Garlic & 16.7 & 8.3 & Radish & 33.3 & 2.2 \\
\hline Garlic leaves & 6.7 & 3.3 & Red pepper & 11.1 & 6.7 \\
\hline Grapefruit & 2.2 & 1.1 & Rollinia & 6.7 & 3.3 \\
\hline Green bean & 11.1 & 4.4 & Seville orange & 3.3 & 1.7 \\
\hline Guava & 8.9 & 5.6 & Soursop & 10.0 & 5.0 \\
\hline Lemon & 5.0 & 3.5 & Spinach & 6.7 & 3.3 \\
\hline Lettuce & 11.1 & 3.3 & Sweet potatoes & 5.3 & 1.6 \\
\hline Mango & 11.1 & 1.3 & Swiss chard & 5.0 & 2.2 \\
\hline Meat & 2.1 & 2.1 & Tomatoes & 11.1 & 5.6 \\
\hline Milk & 1.0 & 1.0 & Water melon & 6.7 & 2.2 \\
\hline Mung bean & 22.2 & 13.3 & Yam & 6.7 & 4.4 \\
\hline
\end{tabular}

The Ministry of Agriculture established maximum retail prices due to the high demand for food products. Prices in italic were published by MINAG (2003). The other prices are those in the free market regulated by supply and demand, located at street 19 and B, Vedado, Havana

One $€$ is about 1 CUC (Cuban Convertible Peso), 1 CUC $=24$ CUP (Cuban Pesos) 


\section{References}

Allison, L. E. (1960). Wet combustion apparatus and procedure for organic and inorganic carbon in soil. Soil Science Society of America Journal, 24, 36-40.

Altieri, M. A. (1999). The ecological role of biodiversity in agroecosystems. Agriculture, Ecosystems \& Environment, 74, 19-31.

Altieri, M. A. (2002). Agroecology: The science of natural resource management for poor farmers in marginal environments. Agriculture, Ecosystems \& Environment, 93, 1-24.

ANPP (Asamblea Nacional del Poder Popular) (1991). Ganadería vacuna. In El programa alimentario (pp. 45-54). Havana: José Martí.

Archard, F., \& Banoin, M. (2003). Fallows, forage production and nutrient transfers by livestock in Niger. Nutrient Cycling in Agroecosystems, 65, 183-189.

Beets, W. C. (1990). Raising and sustaining productivity of smallholder farming systems in the tropics: A handbook of sustainable agricultural development. Alkmaar: AgBé Publishing.

Benavides, J. E. (1998). Árboles y arbustos forrajeros: una alternativa agroforestal para la ganadería. In Agroforestería para la Producción Animal en Latinoamérica. Proceedings of the Electronic Conference (pp. 367-394). Rome: FAO-AGAP.

Boue, O., Redondo, M., Montero, C., Rodríguez, M., \& de la Fuente, J. (1999). Reproductive and safety assessment of vaccination with Gavac against the cattle tick (Boophilus microplus). Theriogenology, $51,1547-1554$.

Breman, H., \& Kessler, J. J. (1995). Woody plants in agro-ecosystems of semi-arid regions. Advanced series in agricultural sciences (Vol. 23). Berlin, Heidelberg, New York: Springer.

CITMA (Ministerio de Ciencia, Tecnología y Medio Ambiente) (1997). Estrategia Nacional Ambiental de la República de Cuba. Havana: CITMA.

Crespo, G., \& Rodríguez, I. (2000). El reciclado de los nutrientes en el sistema suelo-planta-animal. Una contribución al conocimiento cientifico en Cuba. Havana: EDICA.

De Koeijer, T. J., Renkema, J. A., \& Van Mensvoort, J. J. M. (1995). Environmental-economic analysis of mixed crop-livestock farming. Agricultural Systems, 48, 515-530.

De Ridder, N., \& Van Keulen, H. (1990). Some aspects of the role of organic matter in sustainable intensified arable farming systems in the West-African semi-arid-tropics (SAT). Fertilizer Research, 26, 299-310.

De Wit, J., Oldenbroek, J. K., Van Keulen, H., \& Zwart, D. (1995). Criteria for sustainable livestock production: A proposal for implementation. Agriculture, Ecosystems \& Environment, 53, 219-229.

DNSF (Dirección Nacional de Suelos y Fertilizantes) (1982). Manual de interpretación de los suelos. Havana: Ministerio de Agricultura.

Funes, F. (1979). Los pastos y el desarrollo ganadero en Cuba. In F. Funes, G. Febles, M. Sistash, J. J. Suárez, F. Pérez Infante (Eds.), Los Pastos en Cuba, I- Producción (pp. 1-19). Havana: EDICAACPA.

Funes, F., García, L., Bourque, M., Pérez, N., \& Rosset, P. (Eds.). (2002). Sustainable agriculture and resistance: Transforming food production in Cuba. Oakland: Food First Books.

Funes-Monzote, F. R. (1998). Sistemas de producción integrados ganadería-agricultura con bases agroecológicas: Análisis y situación perspectiva para la ganadería cubana. Dissertation, Universidad Internacional de Andalucía.

Funes-Monzote, F. R., \& Monzote, M. (2001). Integrated agroecological systems as a way forward for Cuban agriculture. Livestock Research for Rural Development, 13, 1. Retrieved July 6, 2007 from http://www.cipav.org.co/lrrd/lrrd13/1/fune131.htm.

García Trujillo, R. (1983). Potencial y utilización de los pastos tropicales para la producción de leche. In J. Ugarte, R. S. Herrera, R. Ruiz, R. García, C. M. Vázquez \& A. Senra (Eds.), Los Pastos en Cuba II (pp. 247-298). Havana: EDICA, Instituto de Ciencia Animal.

Giampietro, M., Bukkens, S. F. G., \& Pimentel, D. (1994). Models of energy analysis to assess the performance of food systems. Agricultural Systems, 45, 19-41.

Gliessman, S. R. (2001). Agroecology: Ecological processes in sustainable agriculture. Boca Raton: CRC Lewis.

González, A., Fernández, P., Bu, A., Polanco, C., Aguilar, R., Dresdner, J., et al. (2004). La ganadería en Cuba: desempeño y desafios. Havana: Instituto Nacional de Investigaciones Económicas.

Granma. (2006, Julio 3). Consideraciones del Ministerio de la Agricultura sobre la producción y comercialización de productos agropecuarios. Granma Newsletter.

Haynes, R. J. (1983). Soil acidification induced by leguminous crops. Grass and Forage Science, 38, 1-11. Helyar K. R., \& Porter, W. M. (1989). Soil acidification, its measurement and the processes involved. In A. D. Robson (Ed.), Soil acidity and plant growth (pp. 61-101). Sidney: Academic Press. 
Hernández, A., Paneque, J., Pérez, J. M., Mesa, A., Bosch, D., \& Fuentes, E. (1995). Metodología para la cartografía detallada y evaluación integral de los suelos. Havana: Instituto de Investigaciones de Suelos.

Hernández, A., Pérez, J. M., Bosch, D., \& Rivero, L. (1999). Nueva Versión de clasificación genética de los suelos de Cuba. Havana: Instituto de Investigaciones de Suelos.

Hernández I., Martín G., Milera M., Iglesias J., \& Simón, L. (2001). Alternativas de utilização de árvores em sistemas pecuários. In: M. M. Carvalho, M. J. Alvim, J. Da Costa (Eds.), Opções de sustentabilidade para áreas tropicais e subtropicais (pp. 349-361). Juiz da Fora: EMBRAPA Gado de Leite.

Herrera, R. S. (1990). King grass. Plantación, establecimiento y manejo en Cuba. Havana: EDICA.

Hiernaux P., Fernández-Rivera S., Schlecht E., Turner M., \& Williams, T. O. (1998). Livestock mediated nutrient transfers in Sahelian agro-ecosystems. In G. Renard, A. Neef, K. Becker, M. Von Oppen (Eds.), Soil fertility management in West African land use systems (pp. 339-347). Weikersheim: Margraf Verlag.

Hilhorst, G. J., Oenema, J., \& Van Keulen, H. (2001). Nitrogen management on experimental farm 'De Marke': Farming system, objectives and results. Netherlands Journal of Agricultural Science, 49, $135-151$.

Houba, V. J. G., Van der Lee, J. J., \& Novozamsky, I. (1997). Soil analysis procedures: Other procedures (soil and plant analysis, part 5B). Wageningen: Wageningen Agricultural University.

Lantinga, E. A., Oomen, G. J. M., \& Schiere, J. B. (2004). Nitrogen efficiency in mixed farming systems. Journal of Crop Improvement, 12, 437-455.

Ledgard, S. F., \& Steele, K. W. (1992). Biological nitrogen fixation in mixed legume/grass pastures. Plant and Soil, 141, 137-153.

MINAG (Ministerio de la Agricultura) (2003). Precios máximos de venta en los mercados agropecuarios estatales del sistema del Ministerio de la Agricultura. Tribuna de La Habana, 23, 2.

MINAG (Ministerio de la Agricultura) (2006). Statistical bulletins. Internal documents. Havana: Ministry of Agriculture of Cuba.

Monzote, M. (1982). Mejoramiento de pastizales mediante la inclusión de leguminosas. Dissertation, Instituto Superior de Ciencias Agropecuarias de La Habana.

Monzote, M., Funes-Monzote, F. R., Serrano, D., Suárez, J. J., Martínez, H. L., Pereda, J., et al. (1999). Diseños para la integración ganadería-agricultura a pequeña y mediana escala. Final Report Project CITMA 0800058. Havana: CITMA.

Monzote, M., Muñoz, E., \& Funes-Monzote, F. R. (2002). The integration of crops and livestock. In F. Funes, L. García, M. Bourque, N. Pérez, P. Rosset (Eds.), Sustainable agriculture and resistance: Transforming food production in Cuba (pp. 190-211). Oakland: Food First Books.

Paneque, P. V., Calderón, M., Calaña, N., Carucho, C. M., Hernández, P., \& Borges, Y. (2002). Manual de técnicas analíticas para análisis de suelo, foliar, abonos orgánicos y fertilizantes químicos. Havana: Instituto Nacional de Ciencias Agrícolas.

Pérez-Olaya, L. A. (1998). Regulación biótica de fitófagos en sistemas integrados de agricultura-ganadería. Dissertation, Universidad Agraria de La Habana.

Pérez, R. (1999). La ganadería cubana en transición. World Animal Review, 92, 25-35.

Pimentel, D. (2004). Livestock production and energy use. In Encyclopedia of Energy (pp. 671-676). Cleveland, Amsterdam: Elsevier.

Pimentel, D., Herz, M., Glickstein, M., Zimmerman, R. A., Becker, K., Evans, B. H., et al. (2002). Renewable energy: Current and potential issues. Bioscience, 52, 1111-1120.

Pretty, J. N., Morrison, J. I. L., \& Hine, R. E. (2003). Reducing food poverty by increasing agricultural sustainability in the development countries. Agriculture, Ecosystems \& Environment, 95, 217-234.

Ramón, J., Campa, L., Ojeda, M., \& Vale, V. (1987). Instructivo técnico para el desarrollo de la lombricultura en Cuba. Havana: Ministerio de La Agricultura, Instituto de Investigaciones de Suelos.

Rijo, E. (1996). Lucha biológica contra la garrapata (Boophilus microplus) con hongos entomopatógenos. Dissertation, Instituto de Investigaciones de Sanidad Vegetal.

Rodríguez, M. (1998). Comportamiento de la biota edáfica en sistemas integrados ganadería-agricultura. Technical Report Project CITMA 0800058. Havana: CITMA.

Sosa, M., \& Funes-Monzote, F. R. (1998, December 18). ENERGIA: Sistema computarizado para el análisis de la eficiencia energética. Cuba Patent 03398-3398.

Spedding C. R. W. (1988). An introduction to agricultural systems (2nd ed.). Amsterdam: Elsevier.

SPSS. (1999). Statistical Package for Social Sciences. Release 10.0.5 for Windows. Chicago: SPSS Inc.

Stout, B. A. (1990). Handbook of energy for world agriculture. Amsterdam: Elsevier.

Thomson, E. F., Bahhady, F. A., Nordblom, T. A., \& Harris, H. C. (1995). A model-farm approach to research on crop-livestock integration-III. Benefits of crop-livestock integration and a critique of the approach. Agricultural Systems, 49, 31-44. 
Tukey, J. W. (1977). Exploratory data analysis. Reading, MA: Addison-Wesley.

Vandermeer, J., Van Noordwijk, M., Anderson, J., Ong, Ch., \& Perfecto, I. (1998). Global change and multispecies agroecosystems: Concepts and issues. Agriculture, Ecosystems \& Environment, 67, 1-22.

Van Keulen, H. (2005). Heterogeneity and diversity in less-favoured areas. Agricultural Systems, 88, 1-7.

Van Keulen, H., \& Schiere, H. (2004). Crop-livestock systems: old wine in new bottles? In R. A. Fischer, N. Turner, J. Angus, L. McIntyre, M. Robertson, et al. (Eds.), New directions for a diverse planet. Paper presented at the 4th International Crop Science Congress, Brisbane, Australia, 26 September-1 October. Retrieved July 6, 2007 from www.cropscience.org.au.

WRB (World Reference Base) (2006). World reference base for soil resources 2006. World Soil Reports 103. Rome: FAO. 